\title{
Egg-laying preferences of the xerophilous ecotype of Maculinea alcon (Lepidoptera: Lycaenidae) in the Aggtelek National Park
}

\author{
ERvin ÁRNYAS, Judit BERECZKI, ANDREA TÓTH, KatAlin PECSENYE and Zoltán VARGA
}

Department of Evolutionary Zoology and Human Biology, University of Debrecen, Pf. 3, H-4010 Debrecen, Hungary; e-mail: arnyaser@delfin.klte.hu

Key words. Egg-laying preference, xerophilous ecotype of Maculinea alcon, clumps of Gentiana stems, Aggtelek National Park

\begin{abstract}
The oviposition sites of the xerophilous ecotype of M. alcon (= "Maculinea rebeli") were surveyed in the managed (transitional) zone of the Aggtelek National Park and Biosphere Reserve in Northern Hungary. The M. alcon population is distributed over a territory of about 3 ha. In 2001, habitat reconstruction with selective cutting of shrubs and mowing, was started in this area. The number of stems of Gentiana cruciata (the food plant for the young larvae) and M. alcon eggs layed on them were counted in a selected area within this 3 ha: before (in 1992, 1993 and 1998) and after habitat reconstruction (in 2003, 2004 and 2005). In 2004 and 2005, a detailed study was carried out in order to detect potentially significant factors influencing the egg laying behaviour of females. The average number of intact flowering stems per quadrate was 2.68 and was clearly decreasing before management started. In contrast, there were five times higher (15.06) and increasing numbers of stems per quadrate right after habitat reconstruction. The two periods also differed in the percentage of flowering stems, which was very low before habitat reconstruction. The average number of eggs per square was low (6.8) and fluctuated considerably before management started. In contrast, the egg count was high (160.3) and increased consistently after the site was managed. The short grass sward created in the area proved to be advantageous both for the growth of the host plant and for the Maculinea population. The egg laying preference of the females was positively affected by the number of stems per clump, the height of the stems, the number of whorls with flowers and the difference between the height of the stems of the host plant and the surrounding vegetation. Significantly more eggs were found on large clumps of stems than expected on the basis of their availability for egg-laying. Egg counts were strongly correlated with all the measured characteristics of the food plant, which significantly correlated with each other. The interaction term indicated that the number of whorls with flowers is slightly more influential for egg laying than the other characteristics. There were significantly more eggs on the adaxial surface of the leaves and flower buds than on other parts of the food plant.
\end{abstract}

\section{INTRODUCTION}

Populations of many species of Lepidoptera are in decline all over Europe as a consequence of habitat destruction and fragmentation (van Swaay \& Warren, 1999). This process is especially evident in some Maculinea van Eecke, 1915 (Lepidoptera: Lycaenidae) species, which are threatened due to their special life cycle and habitat requirements and need to be protected all over the continent. Ecological studies have revealed that all Maculinea species have an obligate myrmecophilous way of life and close dependence on various Myrmica Latreille, 1804 species (Hymenoptera: Formicidae) (e.g. Elmes \& Thomas, 1987, 1992; Thomas et al., 1989, 1993; Munguira \& Martin, 1997; Fiedler, 1998). Maculinea imagoes oviposit on specific food plants, and their young larvae first feed in the flowers and fruits, where they complete three larval instars. When they reach the fourth instar they drop to the ground and wait to be discovered by foraging workers of particular Myrmica species, who adopt and take them to their nest. Larval survival is, therefore, dependent on the presence of two resources and the oviposition site selection of the females may be affected by either of them: (i) the specific foodplant as the freshly emerged larvae feed on the green seeds of its host plant; (ii) a particular species of Myrmica to discover the caterpillars, that drop off the food plants (e.g. Fiedler, 1991; van Dyck et al., 2000; Pierce et al., 2002). It is, therefore, of great interest to determine which of these factors influence egg laying by females.

The genus Maculinea is represented in Hungary by 4 species: Maculinea alcon (Denis \& Schiffermüller, 1775) (= M. rebeli Hirschke, 1904, stat. revid. see: Als et al., 2004; Pech et al., 2004; Bereczki et al., 2005), M. arion (Linnaeus, 1758), M. teleius (Bergsträsser, 1779) and $M$. nausithous (Bergsträsser, 1779). Their habitats are, as a rule, traditionally managed semi-natural grasslands: extensively grazed pastures and for the xerophilous ecotype of $M$. alcon (= M. rebeli auct.) and $M$. arion nutrient-poor mountain meadows, and mesophilous or marshy litter meadows for M. alcon (s. str.), M. nausithous and M. teleius. In general, Maculinea populations are in decline in Hungary (Bálint, 1991, 1993), mostly due to the loss or degradation of habitat.

A severe decline was observed in a population of the xerophilous ecotype of $M$. alcon during the second half of the 90-s in the Aggtelek National Park (Tohonya valley, $\mathrm{N}$ of the village Jósvafó, $48^{\circ} 29^{\prime} \mathrm{N} / 20^{\circ} 32^{\prime} \mathrm{E} ; 290 \mathrm{~m}$ a.s.l.). An important indicator of this population decline was a decrease in the number of eggs laid on the host plant, Gentiana cruciata (G. Dósa, pers. comm.). This was due to the degradation of the habitat due to overgrazing and trampling by horses and roe deer (see: description of the study site). A systematic programme of mowing and selective cutting of the shrubs in this habitat at the end of 
the vegetation period was started in 2001. After this, the structure of the habitat changed considerably. Between 2002 and 2004, several aspects of these changes were studied. First the influence of habitat reconstruction on the dynamics of the $M$. alcon population was investigated. Two methods were used in parallel: mark-releaserecapture (Árnyas et al., 2005) and the number and the distribution of eggs determined. Repeated vegetation relevés were also carried out in order to detect the changes in the composition and structure of the vegetation. The effects of management were followed by quantitative surveys of the fauna as well of different groups of soil-inhabiting and phytophagous arthropods. Special attention was given to the occurrence and activity of the species of Myrmica ants known to host the Maculinea larvae.

The main goal of the present work was to analyse the effect of management both on the clumps of Gentiana and number and distribution of Maculinea eggs laid on them. It was also planned to determine the factors influencing the females' choice of food plants; e.g. the pattern, growth and fertility of the stems in the clumps. The number of eggs laid on the flowers/flower buds and the whorls of the host plant were, therefore, investigated. In addition, the correlations between the number of eggs laid and some traits of the food plant e.g. the structure of the clumps, the height of the stems and the number of whorls with flowers were determined. The correlation between oviposition preference and the distribution of nests of the host ant will be discussed in another paper.

\section{MATERIAL AND METHODS}

\section{The species studied}

The taxonomic status of the species Maculinea alcon is highly controversial (e.g. Bálint, 1991, 1993, 1996; Munguira \& Martin, 1997; Wynhoff, 1998). The food plant of the marsh and fen ecotype (= M. alcon alcon) is mostly Gentiana pneumonanthe L. and the host ant species are Myrmica scabrinodis (Nylander, 1846), My. ruginodis (Nylander, 1846) and My. rubra (Linnaeus, 1758). While the food plant of the xerophilous ecotype (i.e. "M. rebeli") is Gentiana cruciata L. and My. sabuleti (Meinert, 1861), My. scabrinodis, My. specioides (Bondroit, 1918) or My. lonae (Finzi, 1927) are its host ant species (Elmes et al., 1991a, b, 1994, 1998; Elmes \& Thomas, 1992; Als et al., 2002). Recent studies, however, have repeatedly demonstrated the multi-species use of host ants (Steiner et al., 2003; Schlick-Steiner et al., 2004; Sielezniew \& Stankiewicz, 2004; Tartally \& Csősz, 2004), the overlap of food plants (M. Dolek, pers. comm.; A. Tartally \& Z. Varga, pers. obs.) and the lack of genetic differentiation between $M$. alcon and M. rebeli (Als et al., 2004; Bereczki et al., 2005). Thus, we can conclude that $M$. alcon and $M$. rebeli do not represent distinct evolutionarily significant units (ESU's, e.g. reviewed by Fraser \& Bernatchez, 2001) but different targets for habitat conservation (i.e. different units of conservation).

\section{Description of the study area}

The population of the xerophilous ecotype of Maculinea alcon analysed in the present study is distributed over a territory of about 3 ha between the Lófej and Tohonya valleys (Fig. 1). The site is a managed (transitional) zone of the Aggtelek National Park and Biosphere Reserve. Within this area, a sam-

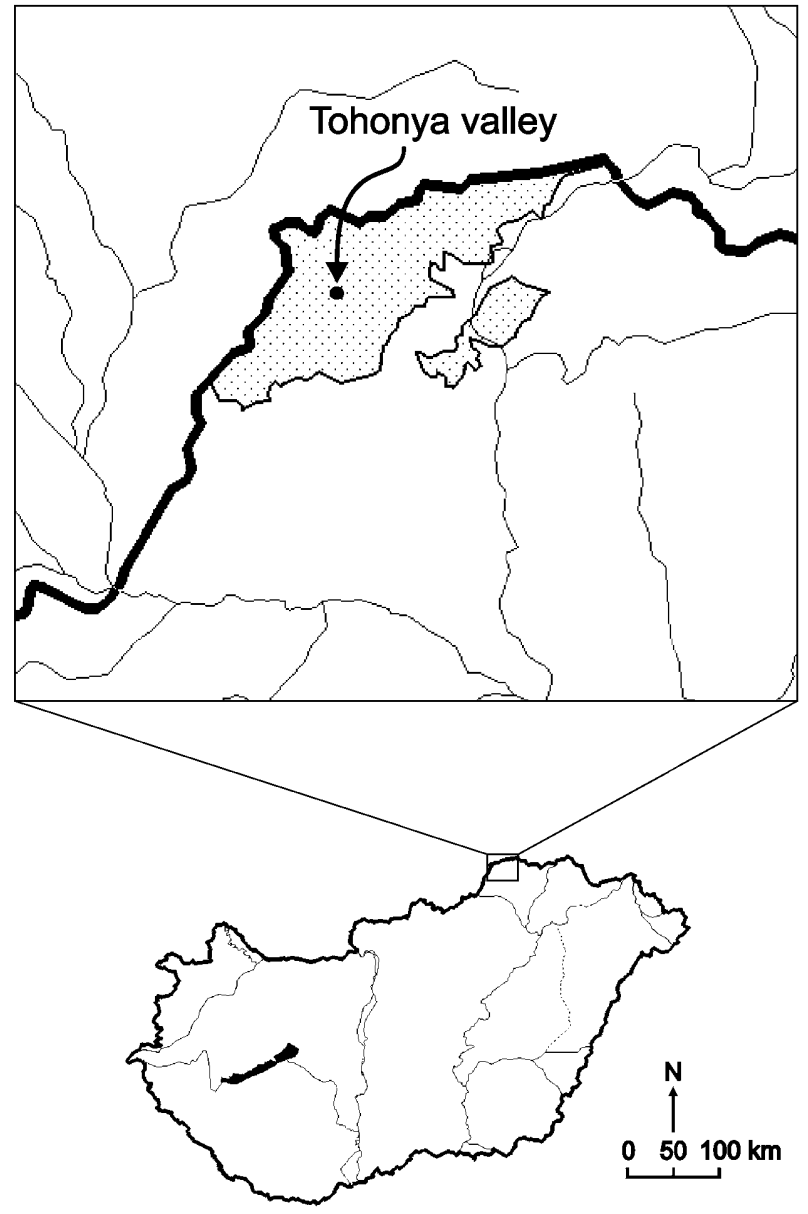

Fig. 1. Location of the study site in the Aggtelek National Park (dotted area).

pling area of $9500 \mathrm{~m}^{2}$, which was subdivided into $10 \mathrm{~m} \times 10 \mathrm{~m}$ squares, was selected. The site was earlier used for game fodder production and was abandoned at the end of the 70's. It was irregularly grazed by cattle or game (mostly roe deer) and rooted by wild boar. During the mid-90's the site was heavily overgrazed by horses, which resulted in the degradation of the vegetation and the dominance of weeds such as Agrimonia eupatoria L., Cirsium arvense (L.) Scop., Stenactis annua (L.) Nees, etc. Moreover, the rooting activity of wild boar intensified as a consequence of the high abundance of Rhizotrogus Berthold, 1827 and Miltotrogus Reitter, 1902 larvae living on Cirsium and Carduus roots. Thus, some ,pioneer" weeds returned like Adonis aestivalis L., Berteroa incana (L.) DC., Bifora radians M. Bieb., Consolida regalis S.F. Gray and Papaver rhoeas L. Associated with this habitat degradation, G. Dósa (pers. comm.) detected a decline in the population size of both Maculinea alcon and Gentiana cruciata. In 2001, the executive of the Aggtelek National Park started a programme of habitat reconstruction with selective cutting of shrubs, mowing and partial shallow harrowing.

Recent surveys of the vegetation give the following composition (Varga-Sipos \& Varga, 1997; Sipos \& Varga, 1998; Varga et al., 2000):

(i) Unharrowed part of the site: Constant and subconstant species: Arrhenatherum elatius (L.) P.B. ex J. et C. Presl (V), Brachypodium pinnatum (L.) P. Beauv. (IV), Festuca rupicola Heuff. (V), Poa pratensis subsp. angustifolia (L.) Gaud. (IV), Agrimonia eupatoria L. (IV), Euphorbia cyparissias L. (V), 


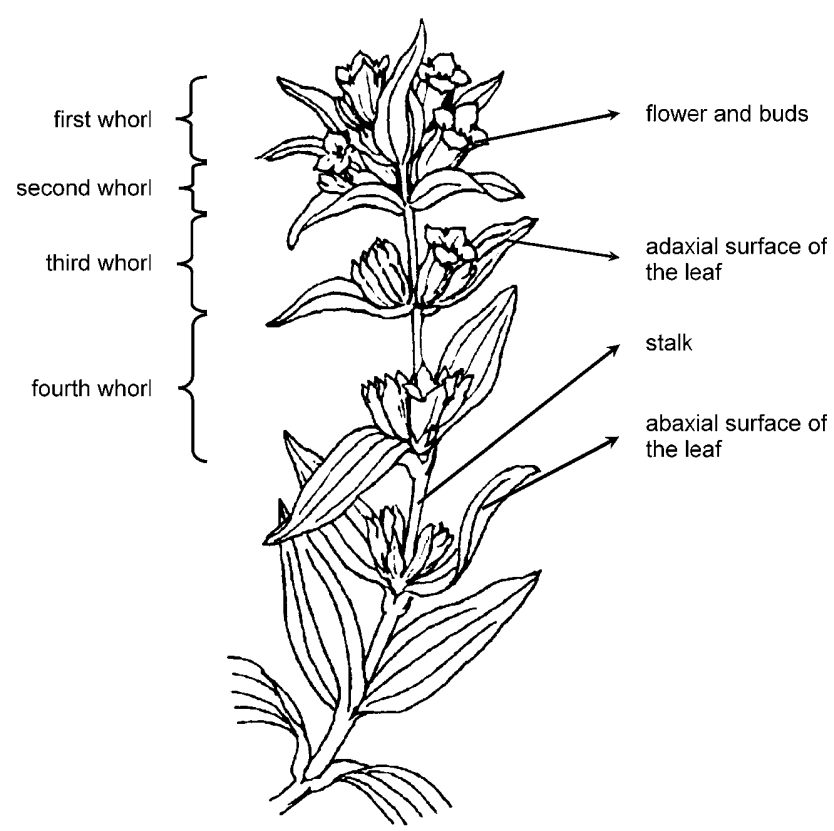

Fig. 2. Parts of a Gentiana stem.

Galium verum L. (V), Leontodon hispidus L. (IV), Plantago media L. (IV), Rumex acetosa L. (IV), Taraxacum officinale Weber. (V) and Trifolium repens L. (IV). Species diversity is relatively high, the number of species varied between $25-37$ per $16 \mathrm{~m}^{2}$.

(ii) Harrowed part of the site: Constant and subconstant species: Poa pratensis subsp. angustifolia (V), Agrimonia eupatoria (IV), Euphorbia cyparissias (IV), Galium verum L. (V), Glechoma hederacea L. (IV), Rumex acetosa (IV), Taraxacum officinale (V), Trifolium pratense L. (IV) and T. repens (V). Species diversity is significantly lower than in the unharrowed part of the site. Species number varied between $17-27$ per 16 $\mathrm{m}^{2}$. The striking differences in the number of species on the two sites are the consequences of patchy overgrazing and trampling by horses.

\section{Sampling}

Initially the geographical coordinates of the site were determined by GPS and a detailed map was constructed of the $190 \mathrm{~m}$ $\times 50 \mathrm{~m}$ sampling area. The area was subdivided into $10 \mathrm{~m} \times 10$ $\mathrm{m}$ squares and the corners were marked by numbered posts. Before habitat reconstruction commenced, the number of stems of G. cruciata and Maculinea eggs were counted in a larger area: 75 squares in 1992 and 1993, and 200 in 1998. In 2003, 20 squares were sampled in a similar manner. In 2004 and 2005, however, a detailed study was made as follows. The clumps of G. cruciata were mapped and counted in 95 and 75 squares in 2004 and 2005, respectively. Eggs were, however, only counted in 50 and 40 randomly selected squares in 2004 and 2005, respectively. The following data were recorded in each of the randomly selected squares (Fig. 2): (i) the number and state of the stems in the clumps of G. crutiata (flowering vs. sterile, intact vs. grazed), (ii) the height of the stems, (iii) the height of the vegetation surrounding the clumps of stems, (iv) the number of whorls with flowers, (v) the number of whorls without flowers, (vi) the number of eggs on the different whorls of the stems: the number on the flowers and buds, on the stalk, on the adaxial surface and abaxial surfaces of leaves. This detailed study was carried out immediately after the flight period of the adults.

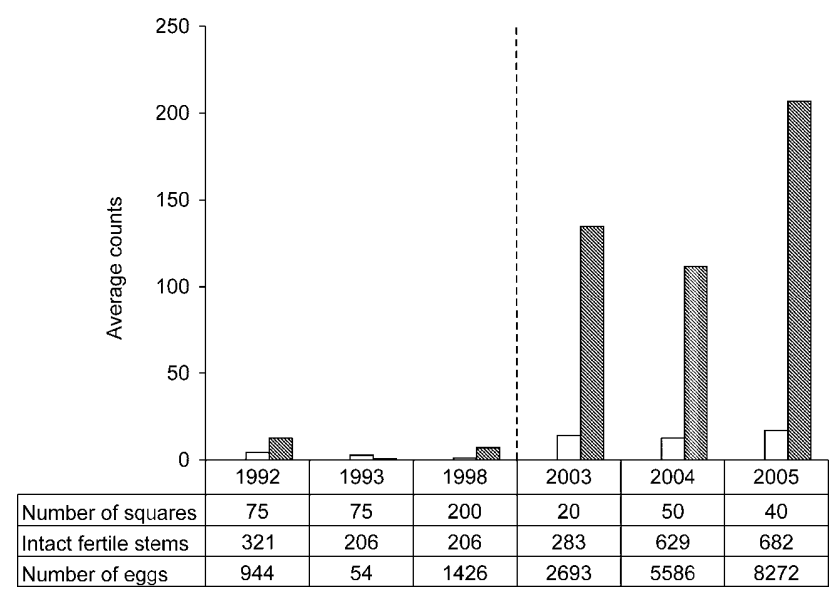

Fig. 3. Chart: Average number of intact fertile stems (open columns) and eggs (hatched columns) per square in each year of the study. Table: The number of squares, intact fertile stems and the total egg count for each year. The start of habitat management is indicated by the dashed line.

\section{Statistical analyses}

The data were analyzed with generalized linear models as counts, that is, a Poisson error with log link function was specified. The distribution of the stems of G. cruciata and eggs were analyzed by Fisher's exact test (Crawley, 1993). Deviance analysis was carried out to investigate the differences in the number of eggs on the different parts of the food plant. Product moment correlation coefficients were estimated between the number of eggs and some characteristics of the food plant (e.g. stem length, number of flowering stems) in order to determine the factors, which might affect egg-laying females. As some of these traits were significantly correlated we also estimated the interaction among them in a multivariate regression model. All analyses were conducted using GLIM 4 (Francis et al., 1994).

\section{RESULTS}

Clumps of Gentiana cruciata were counted and the ratio of intact fertile, sterile and grazed stems calculated every year of the study (Fig. 3). As the number of quadrates sampled varied in the different years the average counts per quadrate were compared. The average number of intact fertile stems per quadrate was very low (2.68) and declining before management started (Fig. 3). In contrast, the number of stems per quadrate was five times larger (15.06) right after habitat reconstruction started and was evidently increasing (Fig. 3). These differences were highly significant $\left(\chi^{2}{ }_{1}=27.4 ; \mathrm{P}<0.001\right)$.

As the clumps of Gentiana cruciata were not analysed in detail every year, the comparison of the populations in the two study periods (before and after the start of management) could only be based on the distribution of fertile, sterile and grazed stems (Fig. 4). The two periods primarily differed in the percentage of grazed and fertile stems (Fig. 4). The percentage of grazed stems was much higher, while that of fertile ones was considerably lower before habitat reconstruction $\left(\chi_{14}^{2}=1467 ; \mathrm{P}<0.001\right)$.

In 2004, clumps of Gentiana cruciata stems were counted in the entire sampling area (95 squares). Thus for that year, it was possible to compare the distribution of 


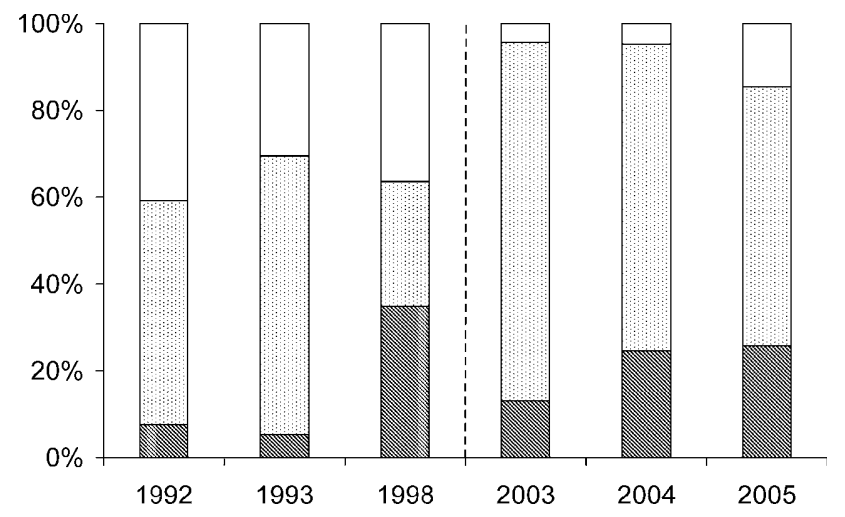

Fig. 4. Percentages of stems of different kinds in each year of the study. Striped bar: intact sterile stems, dotted bar: intact fertile stems, blank bar: grazed stems. The dashed line indicates the beginning of the reconstruction of the area.

the clumps in the total sampling area and the randomly selected 50 squares. A total of 527 clumps were detected on the $9500 \mathrm{~m}^{2}$, while 251 were found in the 50 randomly selected squares. The total number of stems was 1928 in the 95 squares, with an average of 3.65 stems per clump. In the randomly selected squares, 890 stems were counted, which corresponded to 3.54 stems per clump. Stems were classified in two ways. First, the ratio of intact fertile, sterile and grazed stems in the total 95 squares and in the 50 randomly chosen squares, was compared. The distribution of stems differed significantly between the 95 squares and the randomly selected 50 squares $\left(\chi_{2}^{2}=11.9 ; 0.001<\mathrm{P}<0.01\right)$. The difference, however, was in the percentage of grazed stems of which there were a greater percentage in the 50 randomly selected squares $(4.7 \%)$ than in the whole study area $(2.6 \%)$. Nevertheless, most of the stems (approximately $70 \%$ ) were ungrazed and fertile both in the total area and the 50 randomly selected squares. Gentiana clumps were also classified by the number of stems per clump. No significant difference was found in the distribution of stems per clump between the 50 squares and the whole area $\left(\chi^{2}\right.$ $=3.30 ; \mathrm{P}<0.05)$. Clumps consisting of 3-4 stems were the most frequent (approximately 49\%). The percentage of clumps with $1-2$ stems was also high $(26.38 \%$ in the 95 squares and $30.92 \%$ in the randomly chosen 50 squares), while only a few clumps were found with more than 10 stems (of the 6 clumps, 2 were found in the 50 randomly chosen squares). Both the percentage of clumps with 3-4 stems and the number of intact fertile stems were highly similar in the 50 squares and in the whole area. On the basis of these results it was concluded that the number and also the distribution of Gentiana clumps were representative in the 50 randomly chosen squares where the eggs were counted.

As the number of eggs was estimated each year, it was possible to test the effect of management on the number of eggs laid. The average number of eggs per square was quite low (6.8) and very variable before habitat reconstruction (Fig. 3). In contrast, the number of eggs was very high (160.3) and increased consistently after man-
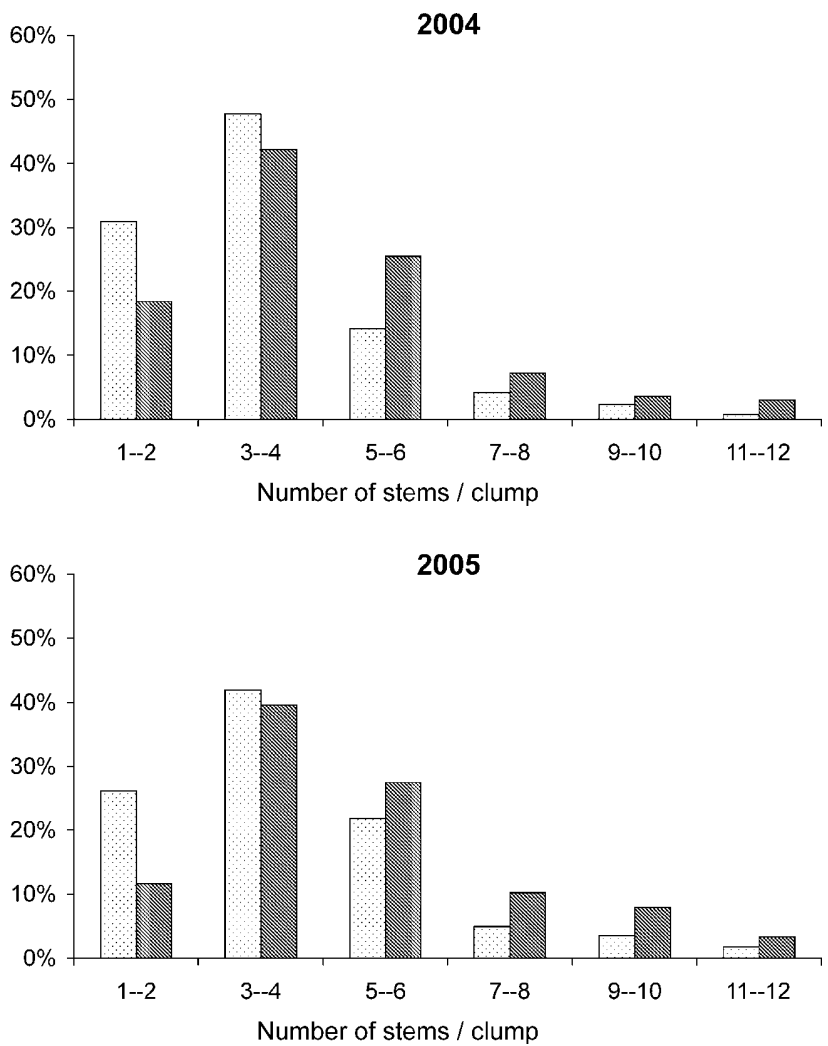

Fig. 5. Percentage distribution of stems and eggs among the gentian clumps with different numbers of stems. Dotted bars: stems; hatched bars: eggs.

agement started (Fig. 3.). The difference in the number of eggs in the two study periods was highly significant $\left(\chi_{1}^{2}=\right.$ 45.4; $\mathrm{P}<0.001)$. Another difference between the two study periods was the distribution of eggs on grazed, intact fertile and sterile stems. Since the percentage of fertile stems was relatively low, before management started, females laid quite a few eggs (15.2\%) on grazed or sterile stems. After 2002, however, the number of intact fertile stems increased considerably and most of the eggs $(98.9 \%)$ were recorded on these stems.

In 2004 and 2005, a detailed study of the association between various characteristics of the food plant and the egg count, was made. First, the distribution of the stems and that of the eggs among the clumps, were compared. Fisher's exact test showed a significant difference between these two distributions. The highest differences were detected for clumps with 5-6 or more stems (Fig. 5). Significantly more eggs were found on these stems than

TABLE 1. The number of eggs on different parts of the first, second, third and fourth whorls of stems of the food plant. Adax: adaxial surface of the leaves; Abax: abaxial surface of the leaves.

\begin{tabular}{crrrr}
\hline Whorl & \multicolumn{1}{c}{1.} & \multicolumn{1}{c}{2.} & 3. & 4. \\
\hline Flower & 1444 & 130 & 77 & 25 \\
Stalk & 37 & 20 & 17 & 3 \\
Adax & 2932 & 232 & 62 & 12 \\
Abax & 571 & 28 & 6 & 3 \\
\hline
\end{tabular}




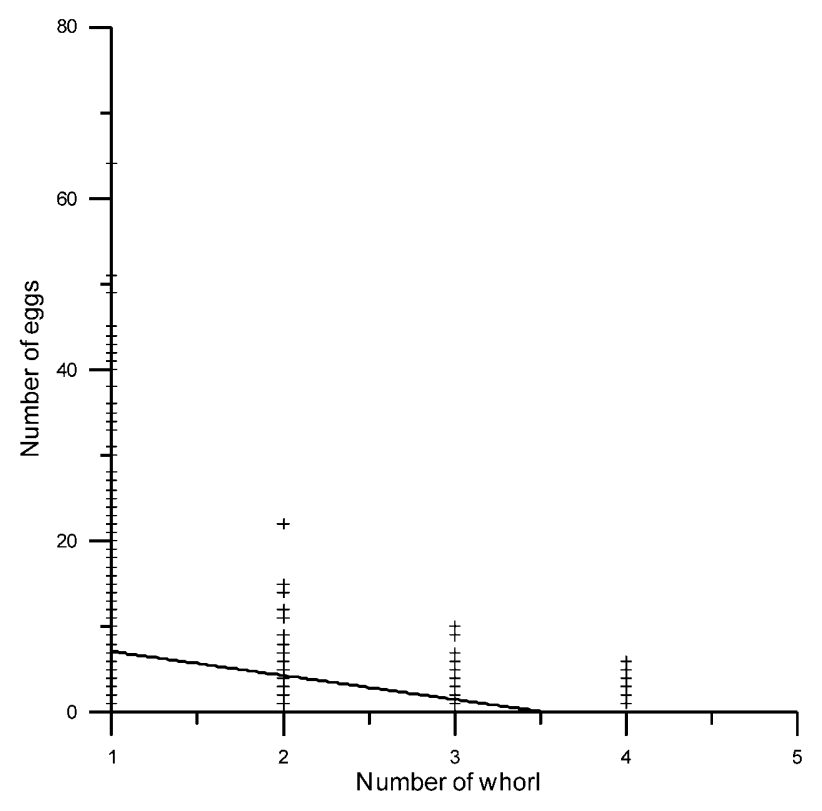

Fig. 6. Correlation between the position of the whorl on the stem and the number of eggs laid on the whorl. Whorls were numbered from the top.

expected on the basis of their availability to the egglaying females (2004: $\chi^{2}{ }_{5}=43.8 ; \mathrm{P}<0.001 ; 2005: \chi^{2}{ }_{5}=$ $59.1 ; \mathrm{P}<0.001)$. It thus appears that females preferred clumps with many stems. This finding apparently contradicts the fact that most of the eggs were found on clumps with 3-4 stems. It is to be noted, however, that $45-50 \%$ of the plants had 3-4 stems.

In the second analysis, the distribution of the eggs on the whorls of each stem was studied. The result was not surprising; females laid $89 \%$ of their eggs on organs of the uppermost whorl. A strong negative correlation was found between the number of eggs and the position

\section{4}

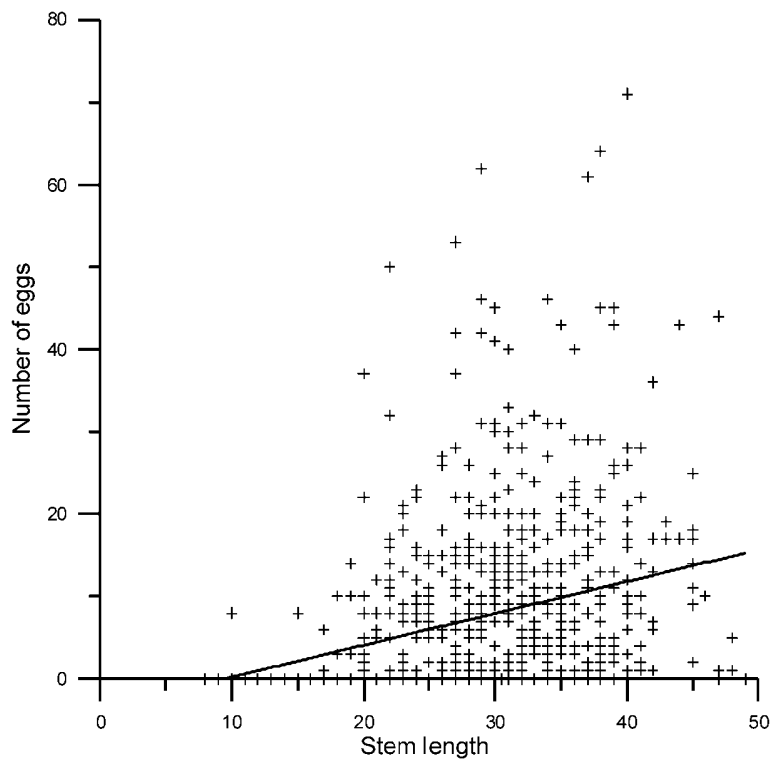

(ordinal number) of the whorls (Fig. $6 ; \mathrm{r}=-0.824 ; \chi^{2}{ }_{1}=$ 29.66; $\mathrm{P}<0.001)$. When the distribution of eggs on the organs of the different whorls (Table 1) was compared, the adaxial surface of the leaves (near to the flowers or flower buds) was clearly the most preferred oviposition site $\left(\chi^{2}{ }_{3}=193 ; \mathrm{P}<0.001\right)$. Hardly any eggs $(0.01 \%$ only $)$ were found on the stalks of the stems.

The next step in the analysis was to look for a correlation between the number of eggs and certain characteristics of the stems. Both in 2004 and in 2005, significantly more eggs were laid on tall than on short stems (Fig. 7: 2004: $\mathrm{r}=0.464 ; \chi_{1}{ }_{1}=196 ; \mathrm{P}<0.001 ; 2005: \mathrm{r}=0.539 ; \chi^{2}{ }_{1}$ $=432 ; \mathrm{P}<0.001)$. A similarly strong correlation was found between the number of whorls with flowers and the number of eggs (Fig. 8; 2004: $\mathrm{r}=0.460 ; \chi^{2}{ }_{1}=192 ; \mathrm{P}<$ $\left.0.001 ; 2005: \mathrm{r}=0.624 ; \chi^{2}{ }_{1}=579 ; \mathrm{P}<0.001\right)$. In 2005 , the height of the surrounding vegetation was measured in addition to stem length. This enables the relationship between these two variables and the number of eggs to be determined. In other words, the effect of stem length relative to the surrounding vegetation could be analysed. They proved to be highly significantly correlated $(\mathrm{r}=$ $\left.0.477 ; \chi^{2}{ }_{1}=337 ; \mathrm{P}<0.001\right)$. It is, however, important to note that all these traits of the stems are correlated with each other. Stem length is strongly correlated both with the number of whorls with flowers (Fig. 9) and the difference between stem length and the height of the surrounding vegetation (number of whorls with flowers 2004: $\mathrm{r}=0.729 ; \chi_{1}^{2}=1134 ; \mathrm{P}<0.001 ; 2005: \mathrm{r}=0,723$; $\chi_{1}^{2}=1525 ; \mathrm{P}<0.001$; difference between stem length and the height of the surrounding vegetation $-2005: \mathrm{r}=$ $\left.0.630 ; \chi^{2}{ }_{1}=1158 ; \mathrm{P}<0.001\right)$. As a consequence, it was of interest to determine the interaction among these factors relative to the egg count. This was achieved by a series of stepwise regression analyses in which the first variable entered was stem length. In this way, the effect of the other two characteristics of stems relative to their length

\section{5}

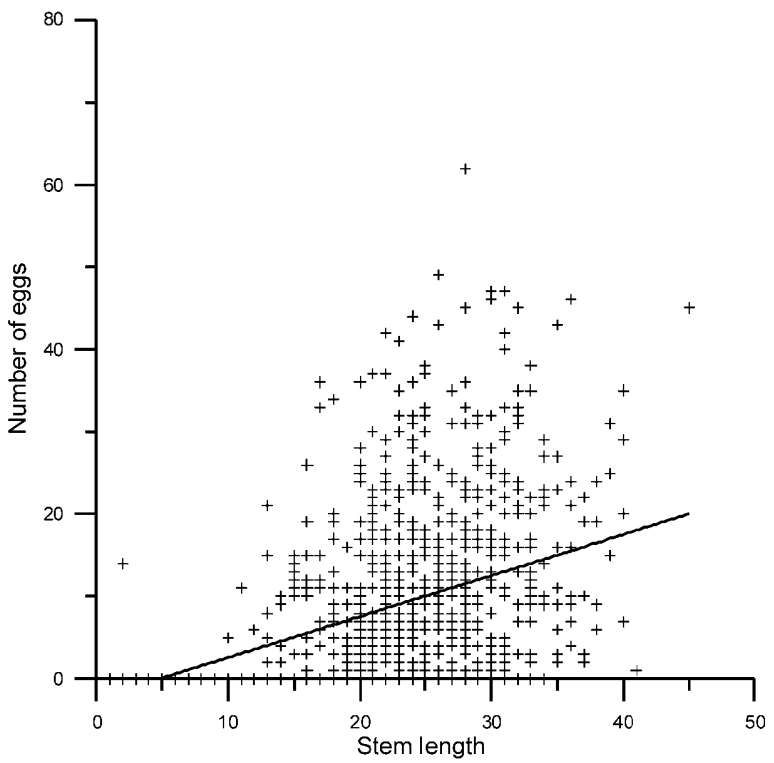

Fig. 7. Correlation between the height of the stems $(\mathrm{cm})$ and the number of eggs laid on them. 

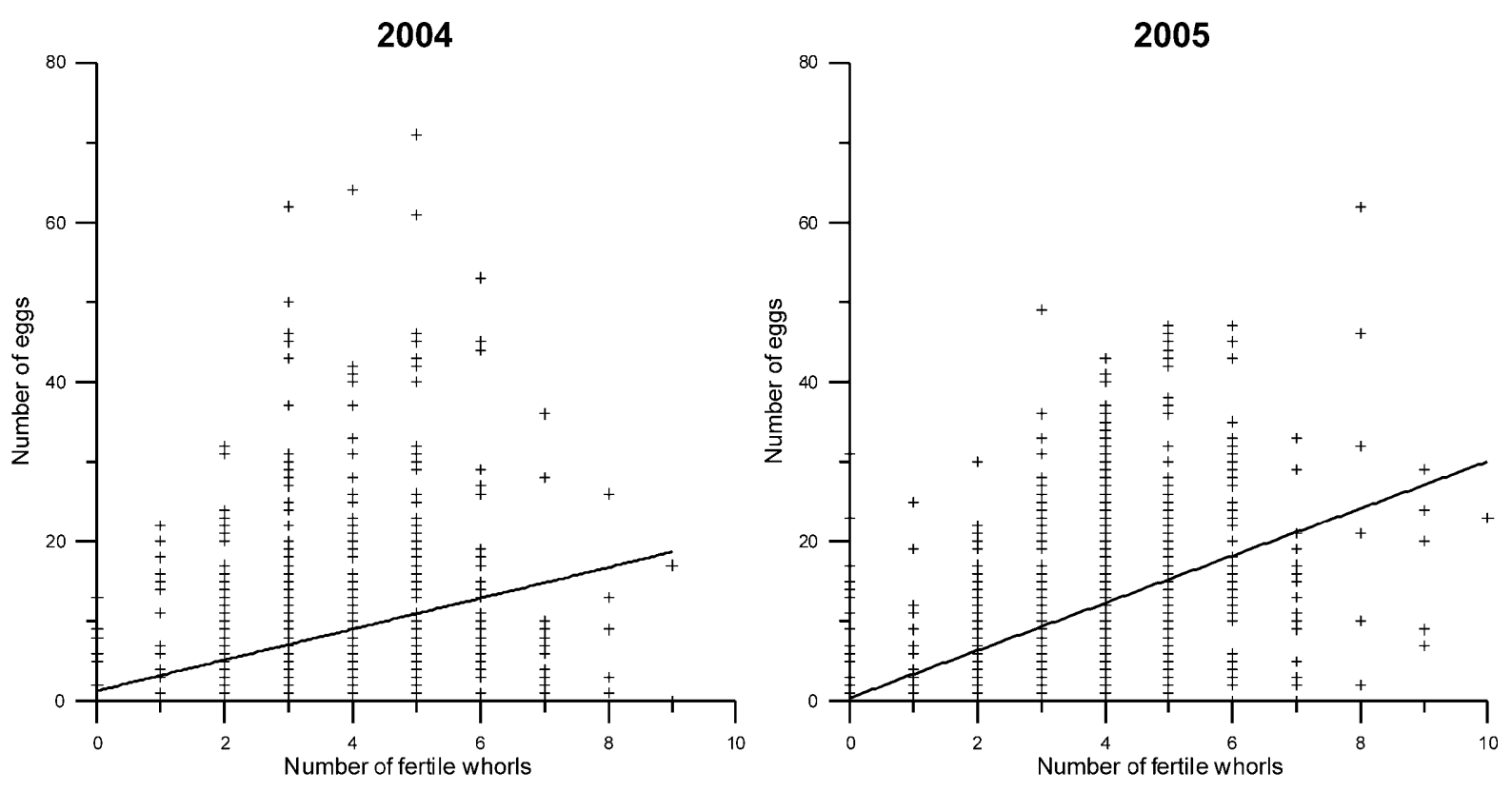

Fig. 8. Correlation between the number of whorls with flowers and the number of eggs laid on them.

was determined. The results clearly showed that the interactions among these traits were highly significant (interaction with the number of whorls with flowers $-2004: \chi^{2}$ $=89 ; \mathrm{P}<0.001 ; 2005: \chi_{1}^{2}=138 ; \mathrm{P}<0.001$; that between stem length and height of the surrounding vegetation 2005: $\left.\chi^{2}{ }_{1}=78 ; \mathrm{P}<0.001\right)$.

\section{DISCUSSION AND CONCLUSIONS}

As data on the number of eggs and clumps of gentian stems accumulated for the three years before and after the start of management of the study area, it was possible to estimate the impact of habitat reconstruction at this $\mathrm{Macu}$ linea site. Both the number of stems and the total egg count increased considerably after management started.
Moreover, the distribution of grazed, intact fertile and sterile clumps significantly improved as the percentage of intact fertile stems increased. This change also influenced the egg laying preference of the females. After the onset of management, all eggs were found on intact fertile stems implying that females preferred intact stems to grazed ones. They only oviposited on damaged stems when the percentage of intact stems was relatively low. Another indication of the recovery of the habitat was that most of the plants counted in 2004 and 2005 were relatively young clumps growing close to each other, which provided ideal egg-laying sites for the butterflies. Thus, we concluded that the food plant was vigorously reproducing vegetatively. In addition to producing seed Gen-
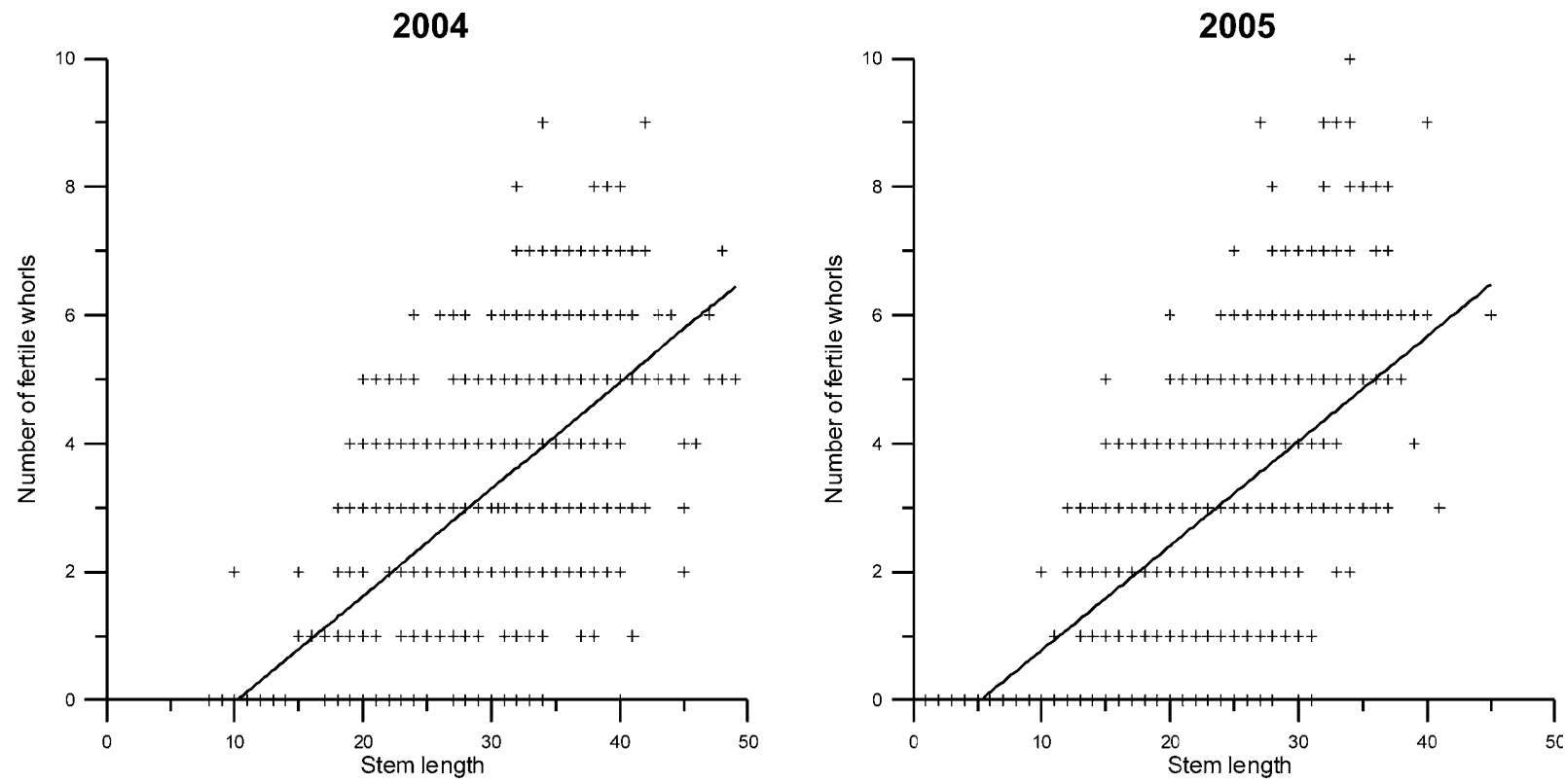

Fig. 9. Correlation between the height of the stems $(\mathrm{cm})$ and the number of fertile whorls. 
tiana cruciata is a hemicryptophyte and reproduces vegetatively giving rise to clumps of stems made up of various numbers of fertile and sterile stems. Thus, gentian population can survive the loss of a large proportion of seeds if the site is suitable for vegetative growth. It is likely the management of the site had a beneficial effect on the vegetative production of clumps of stems and this resulted in the increase in the number of eggs laid on them. Extrapolating from the number of eggs counted to the entire area it is possible to predict the present size of the population. Assuming that the total number of eggs was approx. $13,000-15,000$ on the Tohonya ridge it is predicted that there are several hundred individuals in the population.

Many authors have reported the density and distribution of eggs in various populations of the marshy meadow ecotype of M. alcon (M. alcon s. str., e.g. Hochberg et al., 1994; van Dyck et al., 2000; Nowicki et al., 2005). Egg densities varied greatly (4.7-17.8 eggs per G. pneumonanthe stem) in these studies. The egg laying preference of the xerophilous ecotype of M. alcon is much less studied (Peregovits at al., 2001; Thomas \& Elmes, 2001). Thomas \& Elmes (2001) report that for a long period there was an average of 10.4 eggs per G. cruciata stems, while Peregovits et al. (2001) report 13.3 eggs per stem. In the Tohonya valley the number of eggs was on average 3.3 and 10.1 eggs per stem, before and after habitat reconstruction, respectively. Thus, the egg counts at our study site were initially low but recovered to a normal level after management started. Hochberg et al. (1994) suggest that larval mortality on plants is density independent at egg densities lower than 0.75 eggs per flower and highly density dependent at egg densities greater than this value. It was, therefore, of interest to determine the egg densities at our study site before and after the management. Assuming that one whorl has 5 flowers, our data correspond to approximately $0.2-0.3$ and $0.5-0.6$ eggs per flower before and after management, respectively. It thus appears that even after habitat reconstruction egg densities were below the level when larvae experience density dependent mortality.

Females laid eggs singly or in small groups on the uppermost leaves and flower buds of Gentiana cruciata. In 2004 and 2005, eggs were only laid on intact fertile stems. The egg-laying preference of females was positively affected by the number of stems in a clump. Clumps with 7-8 stems were preferred as they were dense enough and the stems tall enough for the females to find them. In such clumps, the majority of the stems were fertile, although there were occasionally one or two sterile stems. In clumps of Gentiana consisting of many stems relatively few (4-5) of them were tall or of average height. Most of the stems were short and sterile, and thus unsuitable for egg-laying. The positive correlation between the number of stems in a clump and the number of eggs laid on them, however, had certain limitation. That is, egg count did not closely follow the increase in number of stems. The egg-laying capacity of the females is constrained as it is unlikely that they are able to lay their complete egg-load during their short life span of less than 5 days (Wynhoff, 1996; pers. obs.) since freshly emerged females dissected by us at the study site contained between 300-400 eggs.

Other factors influencing the egg laying preference of the females were the height of the stems, the number of whorls with flowers and the difference between the height of the stems and the surrounding vegetation. It was, however, difficult to decide which of these factors were most important as all three were significantly correlated with each other. Moreover, the interaction terms were also similar in the stepwise regression models. Nonetheless, it is likely the number of whorls with flowers is a slightly more important than the other two. Considering the correlations between the number of eggs and the three factors (stem height, number of whorls with flowers and the difference between the height of stems and the surrounding vegetation) the lowest coefficient was obtained for the egg count and the difference between the height of stems and the surrounding vegetation. This implies that the relative height of the stems compared to the surrounding vegetation had a very weak effect on the egg laying behaviour of the females compared to their absolute height. If the most important factor in the egg laying preference of females is the height of the stems then the number of eggs should be more strongly correlated with their relative than absolute height. However, the reverse was found. The most probable explanation of our results is that the main stimulus for oviposition is the number of whorls with flowers, i.e. the flowers themselves. If this is true, even those flowering stems that are slightly lower than the surrounding vegetation will attract females, and consequently the correlation between the relative height of stems and the egg count will be weaker than with the absolute height. This is also supported by field observations, which indicate that searching females can only determine the quality of the food plant from a very short distance or only after touching it.

The egg-laying females preferred to oviposit on certain parts of the food plant. The highest number of eggs were recorded on the adaxial surface of the leaves and flower buds. Nevertheless, only slightly more than half the number of eggs were laid on the flowers compared to the adaxial surface of the leaves. Thus, females appear to prefer to lay eggs on the leaves of the first whorl than on the flower buds. However, the fact that flower buds and flowers provide a much smaller surface for egg-laying than leaves do needs to be taken into consideration. It is, therefore, still acceptable to suggest that relative to their size, flower buds and flowers are the most attractive parts of the stems for females. This is also supported by the fact that the generative organs of Gentiana cruciata only appear at the end of the flight period. As a consequence, females have a smaller chance of laying eggs on them than on other parts of the plant.

ACKNOWLEDGEMENTS. This study was supported by the EU EVK2-CT-2001-00126 (MacMan) project. The authors are grateful to J. Settele, E. Kuehn and S. Gwyllim for the management of the project. The authors thank G. Dósa for permitting us 
the use of the data she collected in the 90's. The authors are grateful to I. Wynhoff and to one anonymous referee for many useful suggestions which have greatly improved the manuscript, and also thank the language editor for the linguistic corrections.

\section{REFERENCES}

Als T.D., Nash D.R. \& Boomsma J.J. 2002: Geographical variation in host-ant specificity of the parasitic butterfly Maculinea alcon in Denmark. Ecol. Entomol. 27: 403-414.

Als T.D., Vila R., Kandul N.P., Nash D.R., Yen S., Hsu Y., Mignault A.A., Boomsma J.J. \& Pierce N.E. 2004: The evolution of alternative parasitic life histories in large blue butterflies. Nature 432: 386-390.

Árnyas E., Bereczki J., Tóth A. \& Varga Z. 2005: Results of the mark-release-recapture studies of a Maculinea rebeli population in the Aggtelek karst ( $\mathrm{N}$ Hungary) between 2002-2004. In Settele J., Kühn E. \& Thomas J.A. (eds): Studies on the Ecology and Conservation of Butterflies in Europe. Vol. 2. Pensoft, Sofia, pp. 111-114.

BÁlint Z. 1991: Conservation of Butterflies in Hungary. Oedippus 3: 5-36.

BÁLINT Z. 1993: The threatened Lycaenids of the Carpathian basin. In New T.S. (ed.): Conservation Biology of Lycaenidae. Occasional Paper of the IUCN Species Survival Commission. No. 8. IUCN, Gland, pp. 105-111.

BÁlint Z. 1996: The Butterflies of the Carpathian Basin. Vol. 1. Magyar Madártani és Természetvédelmi Egyesület, Budapest, 184 pp. [in Hungarian].

Bereczki J., Pecsenye K., Peregovits L. \& Varga Z. 2005: Pattern of genetic differentiation in the Maculinea alcon species group (Lepidoptera, Lycaenidae) in Central Europe. J. Zool. Syst. Evol. Res. 43(3): 157-169.

Crawley M.J. 1993: GLIM for Ecologists. Blackwell, London, $379 \mathrm{pp}$.

Elmes G.W. \& Thomas J.A. 1987: Die Biologie und Ökologie der Ameisen der Gattung Myrmica. In Geiger W. (ed.): Tagfalter und ihre Lebensräume: Arten, Gefährdung und Schutz. Schweizerischer Bund für Naturschutz, Basel, pp. 404-409.

Elmes G.W. \& Thomas J.A. 1992: The complexity of species conservation in managed habitats: interaction between Maculinea butterflies and their host ants. Biodivers. Conserv. 1: $155-169$

Elmes G.W., Thomas J.A. \& Wardlaw J.C. 1991a: Larvae of Maculinea rebeli, a large-blue butterfly, and their Myrmica host ants: wild adoption and behaviour in ant nests. J. Zool. (Lond.) 223: 447-460.

Elmes G.W., Thomas J.A. \& Wardlaw J.C. 1991b: Larvae of Maculinea rebeli, a large-blue butterfly, and their Myrmica host ants: patterns of caterpillar growth and survival. J. Zool. (Lond.) 224: 79-92.

Elmes G.W., Thomas J.A., Hammarstedt O., Munguira M.L., Martin J. \& VAn der Made J.G. 1994: Differences in host-ant specificity between Spanish, Dutch and Swedish populations of the endangered butterfly Maculinea alcon (Denis et Schiff.) (Lepidoptera). Memorab. Zool. 48: 55-98.

Elmes G.W., Thomas J.A., Wardlaw J.C., Hochberg M.E., Clarke R.T. \& Simcox D.J. 1998: The ecology of Myrmica ants in relation to conservation of Maculinea butterflies. $J$. Insect Cons. 2: 69-78.

FIEDLER K. 1991: Systematic, evolutionary and ecological implications of myrmecophily within the Lycaenidae (Insecta: Lepidoptera: Papilionoidea). Bonner Zool. Monogr. No. 31, $210 \mathrm{pp}$.
FIEDLER K. 1998: Lycaenid-ant interactions of the Maculinea type: tracing their historical roots in a comparative framework. J. Insect Cons. 2: 2-15.

Francis B., Green M. \& Payne C. 1994: GliM 4. The Statistical System for Generalised Linear Interactive Modelling. Oxford University Press, Oxford, pp. 531-561.

Fraser D.J. \& Bernatchez L. 2001: Adaptive evolutionary conservation: towards a unified concept for defining conservation units. Mol. Ecol. 10: 2741-2752.

Hochberg M.E., Clarke R.T., Elmes G.W. \& Thomas J.A. 1994: Population dynamic consequences of direct and indirect interactions involving a large blue butterfly and its plant and red ant hosts. J. Anim. Ecol. 63: 375-391.

Munguira M.L. \& Martin J. 1997: Action Plan for the Maculinea Butterflies in Europe. Council of Europe, Strasbourg, pp. 1-96.

Nowicki P., Witek M., Skórka P. \& Woyciechowski M. 2005: Oviposition patterns in the myrmecophilous butterfly Maculinea alcon Denis \& Schiffermüller (Lepidoptera: Lycaenidae) in relation to characteristics of foodplants and presence of ant hosts. Pol. J. Ecol. 53: 105-111.

Pech P., Fric Z., KonvičKa M. \& Zrzavý J. 2004: Phylogeny of Maculinea blues (Lepidoptera: Lycaenidae) based on morphological and ecological characters: evolution of parasitic myrmecophily. Cladistics 20: 362-375.

Peregovits L., Dobos Z. \& Kun A. 2001: A Maculinea alcon xerophila populációökológiája és természetvédelme. [Population ecology and conservation of Maculinea alcon xerophila.] In Borhidi A. \& Dotta-Dukáts Z. (eds): Ökológia az ezredfordulón II. Esettanulmányok. [Millennium in Ecology II. Case studies.] MTA, pp. 27-55 [in Hungarian].

Pierce N.E., Braby M.F., Heath A., Lohmann D.J., Matthew J., Rand D.B. \& Travassos M.A. 2002: The ecology and evolution of the ant association in the Lycaenidae (Lepidoptera). Annu. Rev. Entomol. 47: 733-771.

Schlick-Steiner B.C., Steiner F.M., Höttinger H., Nikiforov A., Mistrik R., Schafellner C., Baier P. \& Christian E. 2004: A butterfly's chemical key to various ant forts: Intersection-odour or aggregate-odour multi-host mimicry? Naturwissenschaften 91: 209-214.

Sielezniew M. \& Stankiewicz A.M. 2004: Simultaneous exploitation of Myrmica vandeli and M. scabrinodis (Hymenoptera: Formicidae) colonies by the endangered myrmecophilous butterfly Maculinea alcon (Lepidoptera: Lycaenidae). Eur. J. Entomol. 101: 693-696.

SiPos J.V. \& VARGa Z. 1998: Phytocenology of semi-dry grasslands (Cirsio-Brachypodion pinnati) in the Aggtelek karst area. Kitaibelia 3: 347-348 [in Hungarian, English abstr.].

Steiner F.M., Sielezniew M., Schlick-Steiner B.C., Höttinger H., Stankiewicz A. \& Górnicki A. 2003: Host specificity revisited: New data on Myrmica host ants of the Lycaenid butterfly Maculinea rebeli. J. Insect Cons. 7: 1-6.

TARTAlly A. \& Csösz S. 2004: Data on the ant hosts of the Maculinea butterflies (Lepidoptera: Lycaenidae) of Hungary. Term. Véd. Közlem. 11: 309-317 [in Hungarian, English abstr.].

Thomas J.A. \& Elmes G.W. 2001: Food-plant niche selection rather than the presence of ant nests explains oviposition patterns in the myrmecophilous butterfly genus Maculinea. Proc. R. Soc. Lond. (B) 268: 471-477.

Thomas J.A., Elmes G.W., Wardlaw J.C. \& Woyciechowski M. 1989: Host specificity among Maculinea butterflies in Myrmica ant nests. Oecologia 79: 452-457.

Thomas J.A., Elmes G.W. \& Wardlaw J.C. 1993: Contest competition among Maculinea rebeli butterfly larvae in ant nests. Ecol. Entomol. 18: 73-76. 
Van Dyck H., Oostermeijer J.G.B., Talloen W., Feenstra V., van der Hidde A. \& Wynhoff I. 2000: Does the presence of ant nests matter for oviposition to a specialized myrmecophilous Maculinea butterfly? Proc. R. Soc. Lond. (B) 267: 861-866.

Van Swahy C.A.M. \& Warren M.S. 1999: Red Data Book of European Butterflies (Rhopalocera). Nature and Environment, No. 99. Council of Europe Publishing, Strasbourg, 260 pp.

VARga-Sipos J. \& VARGa Z. 1997: Phytocenology of semi-dry grasslands in the Aggtelek karst area (N Hungary). In Tóth E. \& Horváth R. (eds): Research in the Aggtelek National Park and Biosphere Reserve. Proceedings of the Conference. Vol. 2. ANP Directorate, Aggtelek, pp. 59-78.

VARga Z., Varga-Sipos J., OrCI K.M. \& RÁcz I. 2000: Semi-dry swards on the Aggtelek karst: phytocenological conditions, Orthoptera and Lepidoptera assemblages. In Virágh K. \& Kun A. (eds): Vegetáció és Dinamizmus. MTA ÖBKI, Vácrátót, pp. 195-238 [in Hungarian].

Wynhoff I. 1996: International Maculinea Workshop. Dutch Butterfly Conservation, Wageningen, $71 \mathrm{pp}$.

WynhofF I. 1998: The recent distribution of the European Maculinea species. J. Insect Cons. 2: 15-27.

Received May 18, 2005; revised and accepted January 27, 2006 